\title{
Comparison of vancomycin serum levels prior to and post therapeutic drug monitoring in patients admitted to hospital
}

\section{Porównanie stężenia wankomycyny w surowicy przed zastosowaniem i po zastosowaniu terapeutycznego monitorowania leku u hospitalizowanych pacjentów}

\author{
Kaveh Eslami ${ }^{1}$, Sasan Moogahi², Reza Ganji ${ }^{1}$, Farhad Najmeddin ${ }^{3}$, Sorour Moogahi ${ }^{4}$ \\ ${ }^{1}$ Department of Clinical Pharmacy, Faculty of Pharmacy, Ahvaz Jundishapur University of Medical Sciences, Ahvaz, Iran \\ ${ }^{2}$ Infectious and Tropical Disease Research Centre, Health Research Institute, School of Medicine, Ahvaz Jundishapur University \\ of Medical Sciences, Ahvaz, Iran. \\ ${ }^{3}$ Department of Clinical Pharmacy, Faculty of Pharmacy, Tehran University of Medical Sciences, Tehran, Iran \\ ${ }^{4}$ School of Pharmacy, Student Research Committee, Ahvaz Jundishapur University of Medical Sciences, Ahvaz, Iran
}

Medical Studies/Studia Medyczne 2021; 37 (3): 187-192 DOI: https://doi.org/10.5114/ms.2021.109565

Key words: therapeutic drug monitoring, infection, antibiotics, vancomycin.

Słowa kluczowe: terapeutyczne monitorowanie leku, zakażenie, antybiotyki, wankomycyna.

\begin{abstract}
Introduction: Vancomycin is of clinical importance because it is the last line of defence against bacteria.

Aim of the research: To compare serum levels of vancomycin before and after therapeutic drug monitoring (TDM) by a pharmacist in hospitalized patients.

Material and methods: This prospective interventional study was performed on 30 patients admitted to the Infectious Disease Ward of Ahvaz Razi Hospital in 2019. In order to determine serum levels, peripheral blood samples were taken from patients in 2 stages ( $2 \mathrm{ml}$ each time) before and 3 days after changing dose of vancomycin. For the patients, a checklist including demographic and clinical information (case number, gender, age, weight, underlying disease, site of infection, prescription dose, serum level, and type of microorganism) was completed.

Results: The mean age of patients was 44.67 years and 53.3\% were female. Serum level of the drug in $86.66 \%$ of patients did not correspond to the therapeutic range. In $33.33 \%$ of patients the dose based on weight and GFR did not correspond to the optimum dose, and in $86.66 \%$ of patients the serum was not at the desirable level. Overall, 26 patients recovered and were discharged, and 4 patients, who had an undesirable level of serum, died. The results of the study showed that by calculating the dose according to the initial criteria, it did not reach the desired level, and the presence of different diseases in patients receiving vancomycin and different drugs makes TDM necessary.

Conclusions: Because there is not much time to intervene due to discharging patients or discontinuation of medication, designing a system to accelerate the TDM process is suggested.
\end{abstract}

\section{Streszczenie}

Wprowadzenie: Wankomycyna ma istotne znaczenie kliniczne jako „lek ostatniej szansy” w niektórych ciężkich zakażeniach bakteryjnych.

Cel pracy: Porównanie stężeń wankomycyny w surowicy przed terapeutycznym monitorowanie leku (TDM) i po nim przez farmaceutę u hospitalizowanych pacjentów.

Materiał i metody: Badanie prospektywne przeprowadzono w grupie 30 pacjentów przyjętych na oddział chorób zakaźnych szpitala Razi w mieście Ahwaz (Iran) w 2019 roku. Aby określić stężenie leku w surowicy, od pacjentów dwukrotnie pobrano próbki krwi obwodowej (każdorazowo po $2 \mathrm{ml}$ ): przed zmianą i 3 dni po zmianie dawki wankomycyny. Dla wszystkich pacjentów wypełniono listę zawierającą dane demograficzne i kliniczne (numer przypadku, płeć, wiek, masa ciała, choroba podstawowa, miejsce zakażenia, przepisana dawka leku, stężenie leku w surowicy i rodzaj drobnoustroju wywołującego zakażenie).

Wyniki: Średni wiek pacjentów wynosił 44,67 roku. Kobiety stanowiły 53,3\% badanej grupy. U 86,66\% pacjentów stężenie leku w surowicy nie mieściło się w zakresie normy. U 33,33\% chorych dawka ustalona na podstawie masy ciała i wskaźnika filtracji kłębuszkowej nie stanowiła dawki optymalnej, a u 86,66\% pacjentów stężenie leku w surowicy nie odpowiadało wartości pożądanej. Stan 26 pacjentów uległ poprawie i wypisano ich do domu. Czterech pacjentów, u których stężenie leku 
w surowicy nie mieściło się w granicach normy, zmarło. Wyniki badania wykazały, że obliczając wielkość dawki według podstawowych kryteriów, nie osiągnięto pożądanego stężenia leku. Ze względu na występowanie różnych chorób i stosowanie odmiennych leków u pacjentów otrzymujących wankomycynę zasadne jest stosowanie TDM.

Wnioski: Z uwagi na krótki czas na interwencje terapeutyczne wskutek wypisywania pacjentów lub odstawiania leków przydatne byłoby opracowanie systemu przyspieszającego proces TDM.

\section{Introduction}

Vancomycin and other related glycopeptide antibiotics are of clinical importance because they are often the last line of defence against bacteria that have become resistant to antibiotics [1]. The emergence of vancomycin-resistant enterococci, and more recently vancomycin-resistant Staphylococcus aureus, are of particular concern. Under-dosing contributes to vancomycin resistance and ineffective treatment while over-dosing is associated with toxicity [2]. Vancomycin is likely to bind to the newly created cell wall mucopeptides, disrupt the dialanine-dialanine sequence and weaken the cell wall [1]. However, proper use and proper dosage of this drug are critical. Complications and toxicities of vancomycin may occur if the serum vancomycin concentration is higher or if it is lower than the normal level, where the serum level of the drug will not rise to the therapeutic level, which is one of the most important risk factors for the development of glycopeptide-positive microorganisms [3-5]. The most common adverse reaction is "red man syndrome", characterized by flushing of the upper body and pruritus due to histamine release. Chest pain, hypotension, and muscle spasm may also occur. Other related side effects include ototoxicity, neutropaenia, fixed drug eruptions, fever, and phlebitis [6]. Therefore, a comprehensive plan for the proper use of this drug is essential.

Therapeutic drug monitoring (TDM) is a clinical method of measuring specific drugs at specified intervals to maintain a constant concentration in the patient's bloodstream, thereby optimizing individual dose drug regimens. TDM is not required for most drugs and is mainly used to monitor narrow-spectrum drugs such as vancomycin, drugs with specified pharmacokinetic diversity, drugs whose target concentration is difficult to determine, and drugs that have therapeutic and adverse effects [7]. The TDM hypothesis assumes that there is a definite relationship between dose and plasma or serum drug concentration and between concentration and therapeutic effects. TDM begins with the first drug being administered and includes determining the initial dosage appropriate to the clinical conditions and patient characteristics such as age, weight, organ function, and concurrent drug therapy [8]. Factors to consider when interpreting concentration measurements include sampling time relative to drug dose, dose history, patient response, and drug targets.

\section{Aim of the research}

The purpose of TDM is to use appropriate concentrations of drugs that are difficult to manage, and to optimize clinical outcomes in patients in various clinical conditions [9]. The present study was designed to determine the serum vancomycin levels prior to and post TDM in patients admitted to the infectious diseases ward.

\section{Material and methods}

This study was conducted as a prospective interventional study after approval by the ethics committee of Ahvaz Jundishapur University of Medical Sciences (Code: IR.AJUMS.REC.1398.482). In this study, serum levels of vancomycin prior to and post TDM by a pharmacist in 30 patients admitted to Razi Hospital of Ahvaz in 2019 were compared. Inclusion criteria included hospitalized patients who began receiving vancomycin. Patients who were discharged or died before completing the study were excluded from the study. Sampling was done by a simple non-probability method. After starting vancomycin treatment, a checklist containing demographic and clinical information (case number, sex, age, weight, underlying disease, site of infection, prescription dose, serum level, and type of microorganism) was completed for the studied patients.

The study was conducted in 2 phases:

Phase I: To ensure serum concentrations following administration of doses as shown in Appendix 1, 30 patients were admitted without intervention and indicated vancomycin treatment. Then, $2 \mathrm{ml}$ sterile peripheral blood samples were taken from the patients, by a trained nurse, in Ferinject test tubes and transferred to a valid medical diagnostic laboratory after sampling under standard conditions. Then, after centrifugation in the laboratory, the vancomycin levels were measured using a fluorometric method based on the oxidation of NALT with $\mathrm{Ce}(\mathrm{IV})$ to produce $\mathrm{Ce}(\mathrm{III})$, and its fluorescence was monitored at $350 \mathrm{~nm}$ after excitation at $250 \mathrm{~nm}$ (via Cobas Integra 4 Plus).

Phase II: The result of the test was evaluated by the pharmacist according to Appendix 1, to determine the range (normal, low, or high) of the patient's vancomycin serum level. The physician was instructed to change the dose according to the results of the test. If appropriate, the physician changed the dose received and 3 days later $2 \mathrm{ml}$ sterile peripheral blood samples were taken again. The specimens were then transferred to a valid medical diagnostic laboratory to 
obtain the result of vancomycin dose change under standard conditions.

Blood samples were obtained in the following order:

1. In subjects with normal renal function, $1 \mathrm{~h}$ before receiving the fourth dose of vancomycin.

2 . If the GFR was between 20 and $39,1 \mathrm{~h}$ before the third dose of vancomycin.

3. If the GFR is less than 20, $24 \mathrm{~h}$ after the first dose of vancomycin.

Doses were compared with standard doses according to the Sandford reference book.

\section{Statistical analysis}

Data were analysed using descriptive statistics including frequency distribution tables, graphs, central indices, and appropriate distribution such as mean and standard deviation. A 95\% confidence interval was considered for the indices. The McNemar test was used to investigate the relationship between dose and serum level. All analyses were performed by SPSS (Statistical Package for the Social Sciences) version 23.

\section{Results}

The mean age of the patients was 44.67 years (19 to 77 years). Twenty-three (76.7\%) patients had an underlying disease, most of which were diabetes (16.7\%) (Table 1). Six (20\%) patients had congestive heart failure (CHF) along with other underlying diseases. There was no significant relationship between $\mathrm{CHF}$ and vancomycin $(p>0.05)$ (Table 1$)$.

In many patients $(86.66 \%)$, the serum level of the drug did not correspond to the therapeutic range (Table 2). In $66.66 \%$ of patients, the dose of vancomycin was in accordance with patient weight (Table 3).

Among patients receiving vancomycin, 1 (5\%) had a favourable serum level and $11(55 \%)$ had lower than normal serum levels, but in $8(40 \%)$ patients the serum levels were higher than normal. The Fisher test showed no significant relationship between the dose and the serum level of the patients $(p>0.05)$ (Table 4$)$

Overall, 26 patients recovered and were discharged, and 4 patients died. Of the patients with poor serum levels, $4(0.8 \%)$ patients died, and no patients were reported with good serum levels. There was no significant relationship between desirable serum level and improvement or death of patients $(p>0.05)$ (Table 5).

Concerning the type of microorganism, 2 (6.66\%) cases were Staphylococcus aureus, 1 (3.33\%) case was Escherichia cola, 1 (3.33\%) case was Staphylococcus, 1 (3.33\%) case was Staphylococcus aureus, 1 (3.33\%) case was Meningococcal, and in $24(80 \%)$ cases the culture was negative.

\section{Discussion}

Therapeutic drug monitoring (TDM) is a clinical method of measuring specific drugs, including
Table 1. Relationship between underlying disease and vancomycin dose

\begin{tabular}{|lccc|}
\hline Status of CHF & $\begin{array}{c}\text { Desirable } \\
\text { level }\end{array}$ & $\begin{array}{c}\text { Undesirable } \\
\text { level }\end{array}$ & P-value \\
With CHF, $n(\%)$ & $1(16.7)$ & $5(83.3 \%)$ & 0.99 \\
Without CHF, $n(\%)$ & $3(12.5)$ & $21(87.5)$ & \\
\hline
\end{tabular}

Table 2. Comparison of vancomycin serum level with drug therapeutic range

\begin{tabular}{|c|c|c|c|}
\hline Patients & $\begin{array}{c}\text { Serum/ } \\
\text { vancomycin } \\
\text { level }\end{array}$ & $\begin{array}{l}\text { Therapeutic } \\
\text { range }[\mathrm{mg} / \mathrm{l}]\end{array}$ & $\begin{array}{c}\text { Matching } \\
\text { (Yes/No) }\end{array}$ \\
\hline Case 1 & 6.6 & $20-15$ & No \\
\hline Case 2 & 7.2 & $20-15$ & No \\
\hline Case 3 & 27.5 & $20-15$ & No \\
\hline Case 4 & 31.5 & $20-15$ & No \\
\hline Case 5 & 22.35 & $20-15$ & No \\
\hline Case 6 & 22 & $20-15$ & No \\
\hline Case 7 & 34.15 & $20-15$ & No \\
\hline Case 8 & 33 & $20-15$ & No \\
\hline Case 9 & 19.9 & 20-15 & Yes \\
\hline Case 10 & 21.6 & $20-15$ & No \\
\hline Case 11 & 23.85 & $20-15$ & No \\
\hline Case 12 & 13.9 & $20-15$ & No \\
\hline Case 13 & 16.1 & $20-15$ & Yes \\
\hline Case 14 & 11.4 & 20-15 & No \\
\hline Case 15 & 9.1 & $20-15$ & No \\
\hline Case 16 & 12.1 & $20-15$ & No \\
\hline Case 17 & 6.9 & $20-15$ & No \\
\hline Case 18 & 10.6 & $20-15$ & No \\
\hline Case 19 & 18.51 & $20-15$ & Yes \\
\hline Case 20 & 52.05 & $20-15$ & No \\
\hline Case 21 & 14 & $20-15$ & No \\
\hline Case 22 & 8.9 & $20-15$ & No \\
\hline Case 23 & 1.25 & $20-15$ & No \\
\hline Case 24 & 10.14 & $20-15$ & No \\
\hline Case 25 & 21.4 & $20-15$ & No \\
\hline Case 26 & 15.7 & 20-15 & Yes \\
\hline Case 27 & 13.1 & $20-15$ & No \\
\hline Case 28 & 8.8 & $20-15$ & No \\
\hline Case 29 & 6.8 & $20-15$ & No \\
\hline Case 30 & 10.5 & 20-15 & No \\
\hline
\end{tabular}


Table 3. Accuracy of vancomycin therapeutic dose based on patients' weight

\begin{tabular}{|c|c|c|c|c|c|c|}
\hline Patients & $\begin{array}{c}\text { Serom/vancomycin } \\
\text { level }\end{array}$ & $\begin{array}{c}\text { Standard } \\
\text { therapeutic dose }\end{array}$ & Weight & GFR & $\begin{array}{l}\text { Given } \\
\text { dose }\end{array}$ & $\begin{array}{c}\text { Matching } \\
\text { Yes/No }\end{array}$ \\
\hline Case 1 & 6.6 & $1.2-2.4$ & 80 & 101.49 & $1 \mathrm{~g} / 12 \mathrm{~h}$ & No \\
\hline Case 2 & 7.2 & $1-2.1$ & 70 & 150 & $1 \mathrm{~g} / 12 \mathrm{~h}$ & Yes \\
\hline Case 3 & 27.5 & $0.9-1.8$ & 60 & 125 & $1 \mathrm{~g} / 12 \mathrm{~h}$ & Yes \\
\hline Case 4 & 31.5 & $1.2-2.4$ & 80 & 95.95 & $1 \mathrm{~g} / 12 \mathrm{~h}$ & No \\
\hline Case 5 & 22.35 & $0.7-1.5$ & 53 & 58.27 & $1 \mathrm{~g} / 12 \mathrm{~h}$ & Yes \\
\hline Case 6 & 22 & $0.7-1.5$ & 60 & 47.5 & $1 \mathrm{~g} / 12 \mathrm{~h}$ & Yes \\
\hline Case 7 & 34.15 & $0.7-1.5$ & 50 & 54.43 & $1 \mathrm{~g} / 12 \mathrm{~h}$ & Yes \\
\hline Case 8 & 33 & $1.5-3.1$ & 105 & 85.25 & $1 \mathrm{~g} / 12 \mathrm{~h}$ & No \\
\hline Case 9 & 19.9 & $1.1-2.3$ & 78 & 65.45 & $1 \mathrm{~g} / 12 \mathrm{~h}$ & No \\
\hline Case 10 & 21.6 & $0.9-1.8$ & 60 & 152.77 & $1 \mathrm{~g} / 12 \mathrm{~h}$ & Yes \\
\hline Case 11 & 23.85 & $0.9-1.8$ & 60 & 103.7 & $1 \mathrm{~g} / 12 \mathrm{~h}$ & Yes \\
\hline Case 12 & 13.9 & $1.2-2.5$ & 85 & 97.98 & $1 \mathrm{~g} / 12 \mathrm{~h}$ & No \\
\hline Case 13 & 16.1 & $0.9-1.8$ & 60 & 54.16 & $0.75 \mathrm{~g} / 12 \mathrm{~h}$ & No \\
\hline Case 14 & 11.4 & $0.8-1.7$ & 58 & 135.7 & $1 \mathrm{~g} / 12 \mathrm{~h}$ & Yes \\
\hline Case 15 & 9.1 & $0.8-1.6$ & 55 & 110.38 & $1 \mathrm{~g} / 12 \mathrm{~h}$ & Yes \\
\hline Case 16 & 12.1 & $1.1-2.2$ & 75 & 101.82 & $1 \mathrm{~g} / 12 \mathrm{~h}$ & No \\
\hline Case 17 & 6.9 & $0.1-0.2$ & 65 & 8.03 & $0.5 \mathrm{~g} / 12 \mathrm{~h}$ & Yes \\
\hline Case 18 & 10.6 & $0.9-1.8$ & 63 & 62.82 & $1 \mathrm{~g} / 12 \mathrm{~h}$ & Yes \\
\hline Case 19 & 18.51 & $0.9-1.8$ & 60 & 67.23 & $1 \mathrm{~g} / 12 \mathrm{~h}$ & Yes \\
\hline Case 20 & 52.05 & $0.9-1.8$ & 60 & 64.63 & $1 \mathrm{~g} / 12 \mathrm{~h}$ & Yes \\
\hline Case 21 & 14 & $0.8-1.6$ & 55 & 102.7 & $1 \mathrm{~g} / 12 \mathrm{~h}$ & Yes \\
\hline Case 22 & 8.9 & $0.9-1.8$ & 60 & 58.82 & $1 \mathrm{~g} / 12 \mathrm{~h}$ & Yes \\
\hline Case 23 & 1.25 & $0.9-1.9$ & 65 & 69.76 & $1 \mathrm{~g} / 12 \mathrm{~h}$ & Yes \\
\hline Case 24 & 10.14 & $1.4-2.9$ & 97 & 47.94 & $1 \mathrm{~g} / 12 \mathrm{~h}$ & No \\
\hline Case 25 & 21.4 & $0.8-1.7$ & 57 & 60.56 & $1 \mathrm{~g} / 12 \mathrm{~h}$ & Yes \\
\hline Case 26 & 15.7 & $1.3-2.6$ & 87 & 145.25 & $1 \mathrm{~g} / 12 \mathrm{~h}$ & No \\
\hline Case 27 & 13.1 & $2-1$ & 67 & 90.72 & $1 \mathrm{~g} / 12 \mathrm{~h}$ & Yes \\
\hline Case 28 & 8.8 & $1.2-2.4$ & 80 & 129.07 & $1 \mathrm{~g} / 12 \mathrm{~h}$ & No \\
\hline Case 29 & 6.8 & $0.9-1.9$ & 66 & 83.97 & $1 \mathrm{~g} / 12 \mathrm{~h}$ & Yes \\
\hline Case 30 & 10.5 & $0.9-1.8$ & 60 & 92.96 & $1 \mathrm{~g} / 12 \mathrm{~h}$ & Yes \\
\hline
\end{tabular}

Table 4. Comparison of dose and serum level

\begin{tabular}{|lcccc|}
\hline Dose & \multicolumn{3}{c}{ Serum level } & $P$-value \\
\cline { 2 - 3 } & < Desirable level & Desirable level & $>$ Desirable level & \\
Undesirable dose & $4(40 \%)$ & $3(30 \%)$ & $3(30 \%)$ & 0.21 \\
Desirable dose & $11(55 \%)$ & $1(5 \%)$ & $8(40 \%)$ & \\
\hline
\end{tabular}

Table 5. Relationship between desirable serum levels and improvement or death of patients

\begin{tabular}{|lccc|}
\hline Dose & Improvement & Decease & $P$-value \\
Undesirable & $22(84.6 \%)$ & $4(15.4 \%)$ & 0.99 \\
Desirable & $4(100 \%)$ & 0 & \\
\hline
\end{tabular}


narrow-band drugs such as vancomycin, at specified intervals, to maintain a constant concentration in the patient's bloodstream, thereby optimizing individual dose drug regimens. Its importance is in optimizing the clinical outcomes of patients in different clinical conditions [7]. The mean age of the patients was 46.67 years. $46.7 \%$ of patients were male and $53.3 \%$ were female. There was no relationship between gender and drug concentration. Heart failure affects the volume of distribution, and the volume of distribution is highly effective on vancomycin pharmacokinetics. In the present study, there was no significant difference between the percentage of patients with and without CHF based on favourable or unfavourable serum levels. In $86.66 \%$ of patients, the serum level of the drug did not correspond to the therapeutic range, which was significant. In a study conducted by Arfa et al., of 5 children who received more than 2 doses of vancomycin, the serum level of $85 \%$ of the patients who received vancomycin at low doses was not within the recommended treatment range and was consistent with the rates reported in the present study [10]. In the study, steady-state vancomycin concentration was determined in 46 adult patients with HSCT. More than $90 \%$ of the measured vancomycin concentrations were outside the range of $20-15 \mathrm{mg} / \mathrm{l}$. They concluded that the current vancomycin dose regimen could not lead to serum concentrations in patients who were consistent with the results of the present study (86.66\% discrepancy) [11]. In the study by Suryadevara et al., $94 \%$ of patients received an inappropriate concentration, which was close to the rate reported in the present study [12].

In $66.66 \%$ of patients, the vancomycin treatment dose was in accordance with patient weight. There was no significant relationship between vancomycin dose and serum level. In other words, due to the weight-based dose, the desired level cannot be reached. Therefore, TDM is needed because the dose is higher or lower than normal. The results of a study by Vazin et al. on 60 patients showed an initial dose of vancomycin in $68.63 \%$ of patients and was consistent with the rate reported in the present study (66.66\%) [13]. In a study by Salehifar et al., a vancomycin dose was given in $58 \%$ of patients appropriately and was consistent with the rate reported in the present study [14]. Taheri et al. conducted a study on 51 patients undergoing bone marrow transplantation; $21.6 \%$ of patients received an appropriate dose of vancomycin. This rate was $66.66 \%$ in the present study, which may be due to the type of population studied [9]. In the study of Ayazkhoo et al., which included 104 patients admitted to the emergency department and the infectious and internal medicine departments, the dose of vancomycin in adults was $88.8 \%$ different from the optimal dose $(30 \mathrm{mg} / \mathrm{kg})$. However, in the present study, the dose of vancomycin based on weight was not matched in $33.33 \%$ of patients. The reason for the differences between the 2 studies was probably the type of population under study, because most patients were in the infectious ward in the present study and almost all were in the same condition, and the dose was better calculated in the infectious ward [15]. In the present study, there was no significant relationship between desirable serum level and improvement or death of patients $(p>0.05)$. Given the low sample size, it is not possible to judge that an unfavourable serum level causes an increase in death, but given that no death occurred at the desired serum level it is likely that the serum level is associated with mortality. In another study on 21 patients, $4.9 \%$ had acute kidney injury (AKI) during vancomycin treatment [11].

The present study had several limitations: (1) to determine the serum vancomycin levels after TDM and to compare the difference between vancomycin serum levels prior and post TDM in hospitalized patients, it was not possible to measure serum levels after TDM in hospitalized patients; (3) doctors did not cooperate in changing the dose of vancomycin after TDM; and (4) low sample size.

Given that this test is available and low cost and the therapeutic range of vancomycin is narrow, it is recommended that this test be performed routinely for all patients. The presence of clinical pharmacists along with physicians to adjust the dose of the drug may also be desirable. On the other hand, because there is not much time to intervene due to patients being discharged or discontinued, it is recommended to design a system to accelerate TDM.

\section{Conclusions}

Given that in the present study, in $33.33 \%$ of the cases, the dose based on the patient's weight and GFR did not correspond to the optimal dose, and the serum level was contrasted in $86.66 \%$ of patients with the optimal serum level, weight and creatinine levels should be considered more precisely when administering vancomycin. On the other hand, uncontrolled concentration in the long-term can lead to increased resistance and complications or decreased treatment response. Finally, it is recommended to adjust the TDM based on the patient's subsequent doses. In addition, it was found in this study and similar studies that it is almost impossible to achieve the desired serum level if the dose is higher or lower than normal and in the case of the presence or absence of underlying disease. Therefore, TDM is required in all patients receiving vancomycin.

\section{Acknowledgments}

This paper is the result of the thesis of Sorour Moogahi at Ahvaz Jundishapur University of Medical Sciences with grant number B-98068. The authors of 
this paper hereby show their appreciation to all the subjects who participated in this study.

\section{Conflict of interest}

The authors declare no conflict of interest.

\section{References}

1. Schäfer M, Schneider TR, Sheldrick GM. Crystal structure of vancomycin. Structure 1996; 4: 1509-1515.

2. Bamgbola O. Review of vancomycin-induced renal toxicity: an update. Ther Adv Endocrinol Metab 2016; 7: 136-47.

3. Pritchard L, Baker C, Leggett J, Sehdev P, Brown A, Bayley $\mathrm{KB}$. Increasing vancomycin serum trough concentrations and incidence of nephrotoxicity. Am J Med 2010; 123: 1143-1149.

4. Kitzis MD, Goldstein FW. Monitoring of vancomycin serum levels for the treatment of staphylococcal infections. Clin Microbiol Infect 2006; 12: 92-95.

5. Steinmetz T, Eliakim-Raz N, Goldberg E, Leibovici L, Yahav D. Association of vancomycin serum concentrations with efficacy in patients with MRSA infections: a systematic review and meta-analysis. Clin Microbiol Infect 2015; 21: 665-73.

6. Lopes Rocha JL, Kondo W, Kuchiki Baptista MD, Cunha CA, Flenik Martins LT. Brazil J Infect Dis 2002; 6: 196-200.

7. Patsalos PN, Berry DJ, Bourgeois BFD, Cloyd JC, Glauser TA, Johannessen SI, Leppik IE, Tomson T, Perucca E. Antiepileptic drugs - best practice guidelines for therapeutic drug monitoring: a position paper by the subcommission on therapeutic drug monitoring, ILAE Commission on Therapeutic Strategies. Epilepsia 2008; 49: 1239-1276.

8. Kang JS, Lee MH. Overview of therapeutic drug monitoring. Korean J Inter Med 2009; 24: 1-10.

9. Taheri S, Hayatshahi A, Torkamandi H, Hadjibabaie M, Javadi MR. Vancomycin utilization review in patients undergoing bone marrow transplantation. J Pharm Care 2014; 2: 66-69.

10. Arfa P, Karimi A, Rafiei Tabatabaei S, Fahimzad A, Armin S, Sistanizad M. A prospective study to assess vancomycin serum concentrations inpediatric patients with current dosing guidelines. Iran J Pharm Res 2016; 15: 341-346.

11. Ghehi M T, Rezaee S, Hayatshahi A, Hadjibabaie M, Gholami K, Javadi M, Khoee SH, Radfar M, Esfandbod M, Ghavamzadeh A. Vancomycin pharmacokinetic parameters in patients undergoing hematopoietic stem cell transplantation (HSCT). Int J Hematol Stem Cell Res 2013; 7: 1-9.

12. Suryadevara M, Steidl KE, Probst LA, Shaw J. Inappropriate vancomycin therapeutic drug monitoring in hospitalized pediatric patients increases pediatric trauma and hospital costs. J Pediatr Pharmacol Ther 2012; 17: 159-165.

13. Vazin A, Japoni A, Shahbazi S, Davarpanah MA. Vancomycin utilization evaluation at hematology-oncology ward of a teaching hospital in Iran. Iran J Pharm Res 2012; 11: $163-170$

14. Salehifar E, Babamahmoodi F, Alikhani A, Ganji R, Fazli M, Drug FM. Drug utilization evaluation of vancomycin in a referral infectious center in mazandaran province. J Pharm Care 2014; 2: 55-59.
15. Ayazkhoo L, Mousavi S, Ramazani F, Ayatollahi-Tafti M, Sa'dabadi Z, Sistanizad M. Vancomycin utilization evaluation: are we dosing appropriately? J Pharm Care 2013; 1: $149-152$

\section{Address for correspondence:}

\section{Sasan Moogahi MD}

Infectious and Tropical Disease Research Centre

Health Research Institute

School of Medicine

Ahvaz Jundishapur University of Medical Sciences

Ahvaz, Iran

E-mail: sasanmoogahi2020@gmail.com 